\title{
The Squeeze-out of Minority Shareholders: The Case of Ukraine
}

\author{
OleKSANDRA Kolohoida* \\ IRYNA LUKACH** \\ VALERIIA PoIEdYNOK ${ }^{* * *}$ \\ AnASTASIIA ProKopiUK****
}

\begin{abstract}
The Ukraine, until recently, did not possess a legal framework for the compulsory sale of minority shareholders shares upon takeover of a joint-stock company (squeeze-out). In 2017, with a view of implementing the Directive 2004/25/EC on takeover bids, the national lawmaker adopted new legislation, enabling a person who had acquired a dominant interest in a joint-stock company to require all remaining shareholders to sell them their shares. Since then, squeeze-outs in Ukraine have become a widespread practice.

This paper sheds light onto a range of serious shortcomings of the new law. It became clear that the Ukrainian version of squeeze-out essentially deviates from the course set by the Directive. The situation is further affected by the nearly total absence of the stock market in Ukraine. That results in numerous abuses of the minority shareholders rights and to some extent discredits the ideas of a takeover bid and squeeze-out as such.

The authors assess the Ukrainian legal framework for squeeze-out from broader historic and comparative perspectives, identify its faulty points and offer specific steps that need to be taken to bring the Ukrainian squeezeout practice in line with the European standards.
\end{abstract}

Keywords: public offer, takeover bid, squeeze-out, fair value, deprivation of property.

\section{INTRODUCTION}

The regulation of acquiring a significant interest in a company is closely related to the notion of corporate control. ${ }^{1}$ This understood as a possibility for a shareholder to influence the formation of the will of a legal entity. ${ }^{2}$ Shares, besides their proprietary value, possess additional value residing in the rights conferred on a shareholder. A concentration of a certain percentage of shares that exceeds thresholds of $50 \%, 75 \%$ or $95 \%$ at the hands of the majority shareholder (or a group of shareholders acting in concert) means a takeover and defines the capacity of the majority shareholder to influence business activities of a joint-stock company. However, without the right of squeeze-out, a takeover bid becomes much less attractive for a person who intends to acquire control of the company. ${ }^{3}$

* Professor, Doctor of Law, Faculty of Law, Taras Shevchenko National University of Kyiv, Ukraine a.kolohoida@icloud.com.

** Professor, Doctor of Law, Faculty of Law, Taras Shevchenko National University of Kyiv, Ukraine lukachiryna@gmail.com.

*** Professor, Doctor of Law, Faculty of Law, Taras Shevchenko National University of Kyiv, Ukraine vv.poiedynok@gmail.com.

**** Postgraduate student, Business Law Department, Faculty of Law, Taras Shevchenko National University of Kyiv, Ukraine p.anastasiia@i.ua.

1 Shitkina (2011) 874.

2 Stepanov (2006) 9.

3 Kibenko (2006) 350. 
Control of a joint-stock company may be acquired without purchasing all allocated voting stock ${ }^{4}$ as most decisions are made by a simple majority of votes, while quorum at a general shareholders meeting requires a controlling interest $(50 \%+1$ share $)$. This implies the necessity to establish a certain mechanism that would guarantee the observance of shareholders' rights by the redistribution of corporate control. This is how takeovers occur, aimed at protection of the rights of all shareholders in the target company and payment of fair compensation for taking of control rights, besides the cost of the shares.

\section{SQUEEZE-OUT PROCEDURE IN THE LEGISLATION OF THE EU AND SOME OTHER COUNTRIES}

In due time, all developed corporate legal orders recognized the need of establishing a legal framework for buying out shares from minority shareholders in case of concentration of interest that, as a rule, exceeds 90\%, at one person's hands. Directive 2004/25/EC of the European Parliament and the Council on takeover bids ${ }^{5}$ provides the EU Member States with an option to set the threshold to apply squeeze-out and sell-out independently. However, it cannot be less than $90 \%$ and more than $95 \%$ of the voting shares of the company. Specifically, in Austria, the Czech Republic, Hungary, Poland, Slovenia, Spain and Great Britain, the application threshold of squeeze-out and sell-out makes $90 \%$ of voting shares, while in Bulgaria, Croatia, France, Germany, Italy, Romania and Slovakia, it makes $95 \%$.

There are two major regulatory models of the takeover bid procedure dominating in national legislations - the British model which has become the basis for the European model, and the American model.

The regulators in both models have understood that when there is a mechanism for a company to go public it is also necessary to designate a reverse mechanism for it to go private, as far as to a single shareholder. For that purpose, the procedure of squeeze-out (freeze-out) has been laid down by law. Preserving minorities in a company where the major corporate owner intends to enhance centralization of economic control is a burden to the company in terms of increased expenses e.g., for disclosure of information, facilitating participation of shareholders in business administration, which do not conform to the economic relations established as a result of a takeover bid. ${ }^{6}$

Historically, the first country to introduce the procedure of mandatory offer to purchase shares of public joint-stock companies (takeover bids) was Great Britain after World War II. ${ }^{7}$ Before the formalization of rules on takeover bids, market players observed certain business practice standards and self-developed recommendations which created preconditions for the appearance of the takeover regulation. ${ }^{8}$ In particular, common practice required a person acquiring a controlling interest in the company to make an offer to other shareholders of the target company to purchase their shares on equal terms. ${ }^{9}$

4 Stepanov (2006) 9.

5 Directive 2004/25/EC.

${ }^{6}$ Report of the High Level Group Company Law Experts on Issues Related to Takeover Bids (2002) 60-62.

7 Armour, Jacobs, Milhaupt (2011) 52; Johnston (2007) 423-32.

8 Popov (2012) 13.

9 Johnston (1980) 11. 
A dispersed capital stock became dominant in Great Britain in the early 20th century. Thus, the need arose to introduce a special legal regime for the acquisition of significant interest. The 1950-1960s saw the adoption of takeover rules that comprised norms on takeover bids regarding the sale of all shares of the company and disclosure of information concerning that takeover bid (Notes on Amalgamations of British Companies 1959, 1963). The City Code on Takeovers and Mergers of $1968^{10}$ provided for mandatory offer to buy shares from all shareholders by a person who acquired over $40 \%$ of shares (the threshold was reduced to $30 \%$ in 1974) of the company at the price no lower than the highest price paid by the offeror (or affiliated person and persons acting in concert) in the previous 12 months. That resulted in several sensational takeovers ${ }^{11}$ and in the active lobbying by institutional investors. The adoption of the above-mentioned acts aimed at overcoming the conflict of interests of the majority and minority shareholders, as well as protecting the rights and legitimate interests of the latter. ${ }^{12}$

The City Code developed six fundamental principles of due behaviour of the offeror upon making a takeover bid:

1. the equal treatment principle, safeguarding, in particular, equal conditions and fair price for the shares being acquired

2. giving shareholders necessary time (no less than 2 and no more than 10 weeks) and information to make an informed decision on the bid

3. the neutrality rule i.e., non-interference of the target company board with the decision-making of shareholders on the bid

4. prevention of artificial under- or overpricing of the acquired shares

5. making a bid only in case the offeror is sure of their ability to pay for the shares

6. prohibition of restricting the target company business activities more than necessary due to the bid. ${ }^{13}$

With the adoption of EU Directive 2004/25, ${ }^{14}$ its provisions were included in the Companies Act 2006, ${ }^{15}$ and the rules established in the City Code acquired the force of law.

The takeover mechanism also includes regulation of the squeeze-out procedure (Companies Act 2006, Section 979) which may only be applied in case the offeror becomes the owner of no less than $90 \%$ of the offeree company shares or acquires (firmly contracts acquisition) of no less than $90 \%$ of the offeree company shares as a result of the offer. In those cases, the offeror may require the remaining shareholders to sell their shares at a fair price. The balance of interests shall be provided by the right of minority shareholders who remain after the bid lapsing to demand a sell-out from the shareholder who holds the controlling interest. There are no requirements in Great Britain regarding the calculation of a fair price in cases of squeeze-out because, as a rule, it is the price of shares acquired under an offer. ${ }^{16}$ The shareholder who does not agree to the purchase price shall be entitled to challenge the fairness of the price in court and request larger compensation for purchased shares within six weeks after the moment of sending a notification of purchase.

10 The City Code on Takeovers and Mergers (1968).

11 Skog (1997) 7.

12 Franks, Mayer, Rossi (2005) 581-612.

13 Cooke (2008).

14 Directive 2004/25/EC.

15 Companies Act (2006).

16 Dignam, Allen (2000) 278. 
The American model that regulates the acquisition of significant interest was formed in the late 1980s under the influence of the court practice. It is based on the right of the offeree company directors to act against a takeover in the interests of shareholders or the company by using pre-offer and post-offer defences. In the USA, the 'tender offer' addressed to all shareholders of a public joint-stock company to offer their shares for sale at a specified price $^{17}$ is regulated on two levels - the federal level and the level of individual states, which was introduced in 1968 by the Williams Act that made respective amendments to the Securities Exchange Act. ${ }^{18}$ The traditional definition of a tender offer was provided in Hanson Trust PLC v. ML SCM Corp. (1985), as a depersonalized takeover bid of an individual person or a group of persons to acquire stock of a joint-stock company at the price greatly exceeding the current market price. ${ }^{19}$

One of the characteristic features of federal regulation is that the tender offer is not a binding offer but is addressed to an indefinite circle of persons i.e., it is an offer wherewith the offeror intends to acquire a significant interest in shares, at least 5\% [Securities and Exchange Act, Rule 14 (d)]. The obligation to disclose information is placed upon both the person who intends to acquire shares of the offeree company and the board of directors of the latter. Besides, any person, after acquiring more than $5 \%$ of shares of a public company, shall be obliged to notify thereof the issuer of the securities, the stock exchanges where the securities are traded, as well as the Commission of Securities and Stock Exchanges within 10 days after the acquisition [Securities Exchange Act, Rule 78m (d)]. Besides, the offeror shall specify the basis of acquiring the shares and future plans or intentions regarding the offeree company.

According to Securities Exchange Act the main requirements for a tender offer are:

- the best price rule i.e., the highest price paid by the offeror to any shareholder shall be the price the offeror is obliged to offer to all shareholders [Rule 14d-10 (2)]

- the all-holders rule that provides for equal treatment of all shareholders and, in particular, for making an offer to all shareholders [Rule 14d-10 (1)]

- the requirement for the tender offer to be effective for a specified period of time (Rule 14e-1)

- the right of shareholders to revoke acceptance at any time (Rule 14d-7), whereupon any increase of purchase price under the tender offer shall cover all shareholders who offer shares for sale, even if they agreed to sell at a lower price $[\S 78 \mathrm{n}(\mathrm{d})] .{ }^{20}$

Tender offer regulation at the level of individual states shall be exercised under corporate legislation of states with the Model Business Corporation Act serving as their base. It conveys special rights on shareholders, the most important being the shareholder's right to demand determination of fair value of the shares held by them and subsequent buyout of shares at such fair value (appraisal right). ${ }^{21}$ The legislation of states most often does not describe in detail the method to assess the value of shares held by a minority shareholder. In many states, the price of shares being bought-out is determined as their market price. In the State of Delaware, the court assesses not just the value of shares but also the amount of possible income they may bring. Uniformity of tender offer regulation at the states level is maintained due to the effect of the General Corporation Law of Delaware which often

17 Yoran (Jurkevitz) (1973) 531.

18 Securities Exchange Act (1934).

19 Hanson Trust PLC v. SCM Corp. (1985).

20 Kenyon-Slade (2004) 88-163.

21 Pepin (1992) 960. 
serves as a prototype for corporate laws of other states. Besides, major sources of tender offer regulation at the states level are court precedents and the American Law Institute Restatement of Law.

There are two main types of squeeze-out in the USA:

1. short-form merger - the right to buy out shares is granted to the majority shareholder after reaching the threshold of $90 \%$ of the company's stock. Here minority shareholders' consent is not necessary. The main tool of protection of their rights is the price that exceeds the stock exchange price and includes a premium no less than $30-40 \%$ of the market value

2. long-form merger - buy-out of shares with the preliminary approval of the buy-out terms by the Commission on Securities. The decision on the buy-out shall be made by the extraordinary shareholders meeting, with $75 \%$ of votes in favour of such decision. An additional guarantee is a procedure of determining the purchase price by an independent valuation expert. In case of disagreeing with the valuation, a minority shareholder is entitled to appeal in court.

In general, the law on squeeze-outs in the United States is considered to be much more flexible than in Europe. The reason for this is the different view on shareholders: In Europe, a shareholder is regarded as a holder of property rights whilst the United States view a shareholder as an investor with only a financial interest in the company. In the latter view squeeze-outs are allowed as long as shareholders are guaranteed the fair value of their investment. $^{22}$

Under German legislation, the squeeze-out procedure is applied upon reaching the threshold of $95 \%$ of shares. The valuation of the shares shall be made by an independent valuation expert upon the commission of the majority shareholder. After that, the matter of squeeze-out shall be presented at the general shareholders meeting but its decision under the condition of consolidation of the dominant controlling interest is just a formality. The price of shares cannot be lower than the market value in the last three months. However, this rule does not ensure due protection of minority shareholders' rights as the price of shares is cut down significantly in the period of the company takeover. The price may be appealed against in court which may appoint a different valuation expert to confirm the accuracy of valuation. ${ }^{23}$

Under Swiss legislation, two conditions have to be met to give rise to the squeeze-out right:

1. the takeover bid to acquire securities of the company;

2. acquisition of over $98 \%$ of voting shares by the offeror upon lapsing of the offer.

When the $98 \%$ threshold is reached, the acquisition of the remaining $2 \%$ is quite burdensome for the majority shareholder. After the lapsing of the offer, the offeror shall apply to the court that will define whether the conditions of squeeze-out have been met correctly. $^{24}$

The features of the squeeze-out procedure under the legislation of Poland are:

1. it is impossible to apply the procedure to public companies when a company is in a state of bankruptcy or liquidation;

22 Vos (2015-2116) 119.

23 A guide on public takeovers in Germany (2019) 21.

24 Switzerland Squeeze-out Guide (2010). 
2. the reason for the general shareholders meeting to make a decision on squeeze-out is the need to protect the interests of the company against malpractices and actions of minority shareholders which hinder proper operation of the company;

3. the squeeze-out procedure may be initiated by no more than 5 persons who jointly hold no less than $90 \%$ of the authorized capital;

4. $90 \%$ of shareholders' votes is required to make a decision on squeeze-out;

5 . the decision may concern shareholders who hold less than 5\% voting rights;

6. the squeeze-out price established by the valuation expert makes the minimum price at which the shares are to be acquired;

7. the valuation is independent from both the company and shareholders;

8. a minority shareholder is entitled to appeal against the squeeze-out price in a corporate single-instance court (sąd rejestrowy);

9. a minority shareholder is entitled to appeal against the decision of the general shareholders meeting on squeeze-out in court on grounds laid down for such appeal by law. ${ }^{25}$

The features of the Czech Republic legislation on the squeeze-out procedure are:

1. the squeeze-out procedure is initiated by the general meeting of the offeree company's shareholders;

2. $90 \%$ of shareholders' votes is needed for the general meeting to make a decision on squeeze-out;

3. the decision of the general meeting shall be approved by the National Bank of the Czech Republic within 90 days, otherwise the decision shall be void;

4. valuation of shares shall be performed by a valuation expert appointed by the majority shareholder, with further publication of the valuation report;

5. the National Bank of the Czech Republic is authorized to assess fairness of the squeeze-out price and consider complaints of shareholders regarding the price, as well as regarding violation of their right to choose the moment of squeeze-out;

6. within one month from the moment of publication of the information about the general meeting, any shareholder is entitled to appeal against the squeeze-out price; the court decision regarding such price shall be binding for the majority shareholder;

7. from the moment of publication of the general meeting decision regarding the initiation of the squeeze-out procedure, the shares to be acquired shall be withdrawn from stock exchange trades. ${ }^{26}$

The comparative overview of national squeeze-out laws indicates some common crucial points, in particular, ensuring the fairness of the squeeze-out price and remedies available to the dissatisfied minority shareholder. Ukrainian novel squeeze-out rules will be assessed against this backdrop. Unfortunately, no debate involving comparative arguments preceded the passing of the squeeze-out legislation in Ukraine. There is no evidence that Ukrainian legislator followed any specific foreign model of squeeze-out. Instead, it relied on the idea of implementing the EU Directive on takeover bids. Though, as we aim to show, the results of its interpretation of the EU law are quite controversial.

25 Kodeks spółek handlowych (2000).

26 Commercial code (‘Obchodní zákoník’) (1991). 


\section{SQUEEZE-OUT PROCEDURE IN THE LEGISLATION OF UKRAINE}

On June 4, 2017, Law of Ukraine No. 1983-VIII on amendments to several legislative acts of Ukraine regarding improvement of corporate governance level in joint-stock companies of March 23, 2017 (hereinafter referred to as 'Law No. 1983') entered into force. Law No. 1983 set the legal framework for two ways of consolidation of all company's stock by the majority shareholder who owns over $95 \%$ of shares - mandatory purchase of shares by the majority shareholder upon request of minority shareholders (sell-out procedure) and mandatory bid of the majority shareholder addressed to minority shareholders to sell him/ her their shares (squeeze-out procedure), making amendments and supplements to Law of Ukraine on Joint-Stock-Companies (Articles 65-65 $).{ }^{27}$

Law No.1983 aims to implement Directive 2004/25/EC of the European Parliament and the Council on takeover bids, within the implementation framework of the EU-Ukraine Association Agreement. It should be noted that Directive 2004/25/EC sees the mechanism of granting the person (persons acting in concert), who holds $95 \%$ or more shares of a company the right to perform squeeze-out, in a symbiotic relationship with the corresponding right granted to minority shareholders to require buy-out of their shares by the controlling shareholder at fair value (sell-out).

The necessity to introduce squeeze-out and sell-out procedures stems from the need to improve corporate governance level in joint-stock companies. In the case that a controlling shareholder acquires interest of over $90 \%$ of a company's shares, minority shareholders practically lose the ability to influence a company's activities and decision-making at general meetings. The liquidity of a minority package in that case is reduced and minority shareholders having difficulty in selling their shares at fair value on a stock exchange.

Squeeze-out is a mechanism of a mandatory sale of ordinary shares by minority shareholders based on a depersonalized irrevocable public takeover bid of a person (persons acting in concert) who holds the dominating controlling interest in a company. Article $65^{2}$ of Law of Ukraine on joint-stock companies ${ }^{28}$ grants the right to a person who holds the dominating controlling interest ( $95 \%$ and more of ordinary shares of a joint-stock company), or to any affiliated person, or an authorized person of a group of persons acting in concert, to make an irrevocable public takeover bid to the company to buy shares from all shareholders of the company along with a certified copy of the escrow agreement. In that case, all the company's shareholders, except for persons acting in concert with the offeror, and their affiliated persons and the company itself, are unconditionally obliged to sell their shares to the offeror.

The offeror shall pay the price of shares by making a wire transfer to the escrow account the beneficiaries of which are the shareholders (their heirs, legal successors or other persons who are entitled to receive the funds in accordance with law).

The time limits to exercise the right to public takeover bid are set by law as follows:

1. 90 days from the date of filing the notification to the National Securities and Stock Market Commission by the person (persons acting in concert) who became the owner of the dominating controlling interest as a result of acquiring the company's shares with consideration of the number of shares directly or indirectly held by such person and his/her affiliated persons [Law of Ukraine on joint-stock companies, Art.652 (4)];

27 On amendments to certain legislative acts of Ukraine on increasing the level of corporate governance in joint-stock companies: Law of Ukraine of March 23, 2017.

28 On joint-stock companies: Law of Ukraine of 17 September, 2008. 
2. two years from the date of entry into force of Law No.1983 (from June 4, 2017, till June 4,2019 ) for the person (persons acting in concert) who, as of the date of entry into force by the said Law, was the owner of the dominating controlling interest in shares of a joint-stock company (Final and transitional provisions of Law No.1983, paragraph 2).

The analysis of Law No.1983-VIII shows that it does not conform to Directive 2004/25/EC in a number of aspects.

In the EU countries, the procedure of takeover bid is applied mostly as a mechanism of a public company going private. Some EU countries provide different legal framework of squeeze-out and sell-out procedure for «public» and «private» limited companies. Such diverse regulation can be found in Belgium and Netherlands. ${ }^{29}$ For example, under Belgian Companies' Code the majority shareholder of a private company may require that all the remaining minority security holders sell their securities at an equitable price. ${ }^{30}$ Still, in the EU countries squeeze-outs in private companies are more an exception, than a rule.

In Ukraine there are two types of joint stock companies - public and private. Only a public joint-stock company may make a public offer of its shares, and in a private jointstock company the movement of shareholders is limited by the preferential right of other shareholders to buy shares offered for sale to a third party. The squeeze-out procedure may be used at both public and private joint-stock companies. The Articles of Association of a private joint-stock company may stipulate that the requirements of Articles $65,65^{2}, 65^{3}$ of Law on joint-stock companies shall not cover such company, or cover it only with exceptions or specifics that shall be defined by the Articles of Association of the company. The decision may be made upon the company's formation, or at the general shareholders meeting while making amendments to the Articles of Association, approved by no less than $3 / 4$ of votes of shareholders who had registered to participate in the general meeting.

Private company is an absolutely dominant type of joint-stock companies, as there is practically no public stock market in the Ukraine. In 2014, shares of 126 companies were listed, as of May 1, 2018, the leading Ukrainian Exchange PJSC listed on the second listing level shares of only 4 public joint-stock companies (Donbasenergy PJSC, MHP SE, Motor Sich PJSC, and Ukrnafta PJSC), while out of 224 issuers of corporate obligations only 12 remained listed. As of February 1, 2019, the Ukrainian Exchange PJSC listed only MHP SE shares. That's why in Ukraine squeeze-out is for now predominantly a private company case;

Law No. 1983 has a retroactive nature, i.e. applies to legal relations that had arisen before it entered into force. The shareholders who acquired the dominating controlling interest before the entry into force of Law No. 1983, in particular, in the privatization process, were granted the right to apply squeeze-out procedure within two years from the date of entry into force of Law No. 1983. Such approach contradicts Article 58 of the Constitution of Ukraine saying that laws and regulations have no retroactivity in time, except for cases when they mitigate or cancel liability of a natural person.

It's worth noting that squeeze-outs carried out in the 'offer/bid' phase and those that take place 'retroactively' are somewhat different in terms of determining the price of shares. In the 'offer/bid' squeeze-outs the majority shareholder defines the buyout price as the highest of the three: the biggest purchase price of the shares within the last 12 months, the price determined by the evaluator or the average exchange rate for the last 3 months before the takeover. In 'retroactive' squeeze-out the buyout price bears no relation to the trading record of the last 12 month, instead is determined by the evaluator or according to the average exchange rate of the shares in the exchange register;

29 Gregoriou and Renneboog (2007) 218.

30 Belgium Squeeze-out Guide (2014). 
In the calculation of shares prices, Law on joint-stock companies does not define any special requirements to valuation experts, nor does it provide a mechanism of determining the market value of shares.

Law No.1983 allows non-application of the average stock exchange rate:

1. when the shares are registered on the stock exchange list as non-listed securities;

2. when the shares are traded on the stock market, but it is impossible to define their market value within the time limit set by law;

3. for private joint-stock companies - till May 1, 2018, or lifelong, if the decision on non-application of Article 8 (2) of Law on joint-stock companies was adopted by the general shareholders meeting till April 30, 2018.

In these cases, the price shall be calculated by the valuation agency engaged by the supervisory board of the company, which may allow the supervisory board and the majority shareholder to influence the results of valuation.

Cut-downs of the price of the shares by some issuers has led to a significant decline in the value of assets of public investment funds that accumulate capital of individual investors. In particular, upon application of the squeeze-out procedure under an irrevocable mandatory bid of December 6, 2017 by majority shareholders of Dniproenergo DTEK PJSC the price of shares was established by the Supervisory Board decision as of UAH 488.14, not taking into account the average stock exchange rate of the shares, which made UAH 773.7013 based on the data of Ukrainian Exchange PJSC for the period from May 30, 2017 till August 30, 2017. ${ }^{31}$ During the squeeze-out procedure at Azovstal Metallurgical Complex PrJSC of March 10, 2018, the report on the market value of shares of March 2, 2018 established the price of UAH 0.564 per share, while the stock exchange rate for the shares on February 27, 2018 was fixed at the level of UAH 1.1358 per share. Unfortunately, these cases are not rare.

The determination of market value for the purposes of squeeze-out should be performed by a separate group of qualified evaluators, based on the value of a single ordinary registered share in a $100 \%$ stock of shares.

In October 2018 the National Securities and Stock Market Commission of Ukraine made public a Draft regulation on the register of evaluators, which may conduct independent valuation of securities. The Draft laid down a number of requirements for evaluators. In particular, to be included in the Register, an evaluator should have:

1. had a valid European/international certificate;

2. had in his/her personal portfolio no less than three reports on valuation in the relevant field, complied within the last 12 months;

3 . been engaged in the valuation activities in the relevant field no less than two years;

4. had an impeccable business reputation;

5. complied with the requirements for confidentiality in accordance with the agreements concluded with the employers;

6. been a member of a self-regulatory organisation of evaluators and submit his/her valuation reports to the review of that organization;

7. had neither administrative penalty within the last year nor previous criminal convictions. ${ }^{32}$

${ }^{31}$ Resolution of the National Securities and Stock Market Commission of Ukraine 624-CX-1-E (2018).

32 Draft resolution of the National Securities and Stock Market Commission of Ukraine of 12 October 2018. 
Nevertheless, the Antimonopoly Committee of Ukraine did not approve the Draft due to provisions that, in its view, could impede competition, so the issue remains so far unresolved;

In accordance with para. 22 of Preamble and Article 13 of Directive 2004/25/EC Member States shall lay down rules which govern the conduct of bids, at least as regards the following:

1. the lapsing of bids;

2. the revision of bids;

3. competing bids;

4. the disclosure of the results of bids; (e) the irrevocability of bids and the conditions permitted.

The term 'competing bid' in Directive 2004/25/EC is understood as a bid made after the announced but not completed bid regarding the shares of the same offeree company and addressed to the same circle of shareholders.

Meanwhile, the provisions of Law on joint-stock companies and Section II of Final and transitional provisions of Law No. 1983 do not grant any minority shareholder or any investor, including the State, the right of launching a competing bid to purchase an interest in the company.

A supervisory board is under no obligation to communicate the bid to all shareholders along with its opinion the price of shares, factors that may affect its change and plans of the offeror regarding sale of shares. It is not obliged to obtain and publish the auditor's opinion and documents that made the basis for the calculation of the price, on the company's website. Communicating an opinion of the offeree company board aims to implement one of the basic principles of the City Code - board neutrality by shareholders' decision-making (see also Art. 3(1) (c), 9 of Directive on Takeover Bids). ${ }^{33}$

In this regard, the US experience is also worth discussing. In the famous Smith v Van Gorkom Case (1985) the Delaware Supreme Court held that the Board had a duty to give an informed decision on a merger and could not escape the responsibility by claiming that the shareholders also approved the merger. The Court found the directors to be grossly negligent because they quickly approved the merger without a substantial inquiry or any expert advice. For this reason, the Board breached the duty of care that it owed to the corporation's shareholders. The directors could not rely upon the share price as it contrasted with the market value. And because the Board did not disclose a lack of valuation information to the shareholders, the Board breached their fiduciary duty to disclose all facts germane to a transaction that is subject to a shareholder vote. ${ }^{34}$

The Supervisory Boards members who represent majority shareholder may not be interested in establishing a fair price. To that end O. Kolohoida proposed the rules which now feature in the draft new Law on Joint Stock Companies, Art. 9:

1. on joint liability of supervisory board members before minority shareholders regarding losses caused by the undervaluation of shares;

2. on their obligation to disclose the report on the market value of the shares. ${ }^{35}$

33 Report of the High Level Group of Company Law Experts on Issues Related to Takeover Bids (2002).

34 Smith v. Van Gorkom (1985).

35 Draft law on joint-stock companies (2019). 
Shareholders in private joint-stock companies face additional difficulties to obtain information about the company. Despite the provisions of Articles 25, 77, 78 of Law on joint-stock companies which grant the right to information about a company, in practice the shareholders in private joint-stock companies face obstacles to obtaining reports on assessment of shares market value and annual audit statements, as the information was classified as confidential by the joint-stock company;

In the case of squeeze-out Law on joint-stock companies deprives minority shareholders of the right to participate in distribution of profits, including undistributed profit (dividends) for the previous reporting periods.

The law does not provide any mechanism to protect the rights of minority shareholders in case of any violations in the application of squeeze-out and sell-out procedures. In particular, in 2018 the National Securities and Stock Market Commission acknowledged violation of requirements of Articles 8 and $65^{1}$ of Law on joint-stock companies by Dniproenergo DTEK PJSC in the part of calculating the price of shares. The Commission found that the average stock exchange rate for the shares (UAH 773.70) at Ukrainian Exchange PJSC within three months before the acquisition of dominating controlling interest was not considered. A note of warning was subsequently issued. ${ }^{36}$ Nevertheless, Dniproenergo DTEK PJSC did not act to eliminate the violations, and the squeeze-out procedure at the price of UAH 488.12 per one ordinary share was performed, which resulted in losses suffered by minority shareholders.

\section{CONSTITUTIONAL VALIDITY OF SQUEEZE-OUT}

The analysis of the provisions of Law of Ukraine on joint-stock companies that govern squeeze-out shows that those provisions may violate Articles 3 (on the duty of the state to protect human rights), 8 (on rule of law), 13 (on right of ownership), 21 (on inalienability of human rights), 22 (on prohibition on narrowing the scope of human rights by legislative acts), 41 (on full compensation in case of private property takings) and 58 (on nonretroactivity of laws) of the Constitution of Ukraine as they convey no public interest and clearly defined social purpose, narrow the content and scope of an unalienable and inviolable right of ownership, create preconditions for the use of property to harm a person and the society, do not guarantee prior and complete compensation of property being taken, and are of a retroactive nature.

The outcomes of squeeze-outs at Dniproenergo DTEK PJSC, Zakhidenergo DTEK PJSC, Azovstal Metallurgical Complex PrJSC, and Illich Mariupol Metallurgical Complex PrJSC, as well as at a number of other Ukrainian issuers, demonstrate the necessity to strengthen protection of the rights of minority shareholders in the course of squeeze-out in Ukraine.

To that end, an analysis of decisions of the constitutional courts of several European countries on constitutional validity of the squeeze-out procedure was performed.

The first constitutional court to confirm constitutional validity of depriving minority shareholders of their shares in the process of transformation of a corporate ownership structure, upon condition of strict compliance with law, was the Federal Constitutional Court of Germany in the Feldmühle case. ${ }^{37}$ The Court reiterated its opinion in its decisions

${ }^{36}$ Resolution of the National Securities and Stock Market Commission of Ukraine 624-CX-1-E (2018).

37 BVerfG, 07.08.1962 - 1 BvL 16/60. 
in DAT/Atlanta ${ }^{38}$ and Moto Meter $A G^{39}$ cases. One of the more recent decisions of the Court in a squeeze-out case is the decision of May 30, 2007 (1 BvR 390/04). ${ }^{40}$

The following elements of a legal position regarding squeeze-out procedures can be drawn from the decisions of the Federal Constitutional Court of Germany:

1. deprivation of minority shareholders of their shares in the process of transformation of corporate ownership structure shall be subject to strict compliance with the constitutional principles: equality before law, free development of personality, rule of law, and social nature of the State (Feldmühle, DAT/Atlanta, Moto Meter)

2. the law that governs squeeze-out does not, in itself, deprive shareholders of their possessions (1 BvR 390/04)

3. compensation to minority shareholders for bought-out shares has to be full (Moto Meter, 1 BvR 390/04)

4. the lawmaker did not intend to discriminate against minority shareholders in favour of the majority shareholder (1 BvR 390/04)

5. important safeguards of minority shareholders' rights:

a) an appointment of experts to determine the value of shares by court;

b) bank guarantee of compensation payment for the shares being bought-out;

c) increase of price for the shares if the majority shareholder failed to fulfil the obligation in a timely manner;

d) a possibility of filing a claim to court, which suspends the process of making an entry in the register about the change of owner.

Appeal against the price alone does not suspend the said process (1 BvR 390/04).

The Constitutional Tribunal of Poland in its decision No. 65/6/A/2005 of June 21, $2005,{ }^{41}$ came to the following conclusions:

1. in case of squeeze-out, it goes not about expropriation but about the consequences of deprivation of property similar to expropriation as any deprivation of property regardless of its form, or any restriction or deprivation of any right held by a person, by the government

2. the provisions on squeeze-out unconditionally regulate the situation of property transfer between private bodies against the will of the owner, which has to result in some compensation from the acquirer

3. due compensation shall mean fair compensation that enables the owner to recreate the item lost, or re-establish the property status that existed before the deprivation of property. Such compensation cannot be reduced either by the method of its calculation or means of payment

4. for the minority shareholders whose shares are purchased in the squeeze-out procedure, such compensation shall mean due valuation of their shares that are being purchased

5. the remedies to protect the minority shareholders' interests are:

a) an appeal by a minority shareholder, towards whom there is no sufficient evidence that he made normal operation of the company difficult or impossible with his activities, to the economic court against the decisions of the general meeting on the grounds of violation of law, company articles, business customs, aimed to cause damage to the said shareholder and abuse of rights by the majority shareholder.

381 BvR 1613/94.

$391 \mathrm{BvR} 68 / 95$.

401 BvR 390/04.

41 Trybunał Konstytucyjny 65/6/A/2005. 
Such appeal shall not suspend the squeeze-out procedure. In case the appeal succeeds, the decision of the general meeting shall be declared void, and the shares returned to the minority shareholder in question;

b) an appeal against the price established by the valuation expert.

The decision of the Czech Constitutional Court of March 27, 2008, regarding case Pl.ÚS 56/05: Squeeze-out ${ }^{42}$ states the following:

1. the use of a forced buy-out does not rule out interference in the constitutionally guaranteed rights of shareholders, but that possibility alone does not make the regulation unconstitutional. That could happen only if the state, within its protective function, did not provide minority shareholders with remedies for legal protection;

2. as such interference in the ownership right is regulated by law, it is it is not necessary to consider the question of the public interest in the same procedure as for expropriation;

3. the role of the State is to control compliance with law during general meetings of shareholders that approve the decision on the application of the squeeze-out procedure and providing measures to protect the rights of minority shareholders, if necessary;

4. the court may establish the fact of presence or absence of remedies to protect the shareholders' rights and availability of guarantees of their enjoyment, but it cannot assess the proportionality of the shares price as such;

5. upon determining proportionality of the shares price, it is necessary to consider all the circumstances of squeeze-out;

6. appointment of a share valuation expert by the majority shareholder does not create non-constitutionality of legislation in the part of regulation of the price calculation, as well as the fact of payment of services of such expert at the expense of the majority shareholder, if it is compensated by other remedies provided by the State.

Upon generalizing the legal positions of the Constitutional Court of the Russian Federation and the Supreme Arbitration Court of the Russian Federation on the application of legislation that governs the squeeze-out procedure (decisions No. 681-O- $\Pi,{ }^{43}$ No. $713-\mathrm{O}-$ $\Pi,{ }^{44}$ No. 714-O- $\Pi^{45}$ of July 03, 2007, and No. 949-O ${ }^{46}$ of May 29, 2012, Resolution No. 3- $\Pi^{47}$ of February 24, 2004), the following should be stated:

1. The Constitutional Court of the Russian Federation acknowledged that Russian provisions on squeeze-out as such do not violate the right of ownership (decision No. 949$\mathrm{O}$ ); the fair balance of majority and minority shareholders' interests shall be deemed achieved subject to the following conditions: a) the right to squeeze-out arising upon circumstances clearly defined by legislation; b) obtaining fair price for purchased securities by minority shareholders (decisions No. 681-O-П, No. 713-O-П, No. 714-O-П).

2. The Constitutional Court of the Russian Federation, referring to the European Court of Human Rights in the Sovtransavtoholding v. Ukraine case, stated that the guarantee of protection of the minority shareholders' rights lies in the establishment of efficient judicial control over the squeeze-out procedure, which includes:

a) assessment of the accuracy of the purchased shares valuation by the court;

42 2008/03/27- Pl.ÚS 56/05: Squeeze-out.

43 Decision of the Constitutional Court of the Russian Federation of July 3, 2007 No. 681-O-П.

44 Decision of the Constitutional Court of the Russian Federation of July 3, 2007 No. 713-O-P.

45 Decision of the Constitutional Court of the Russian Federation of March 7, 2007 No. 714-OP.

46 Decision of the Constitutional Court of the Russian Federation of May 29, 2012 No. 949-O.

47 Resolution of the Constitutional Court of the Russian Federation of February 24, 2004 No. 3-P. 
b) existence of losses suffered by a minority shareholder, caused by incorrect valuation;

c) investigation of factual circumstances that may prove significant violations of law or abuse of rights, and affect the determination of fair price of shares (Resolution No. 3-П of February 24, 2004).

3. The Supreme Arbitration Court of the Russian Federation, in Resolution No. 443/11 of September 13,2011 $1^{48}$ stated that, considering the need to protect the minority shareholders' interests, the market price per one share should be calculated in a $100 \%$ stock without adjustment to majority and minority stock of shares. In Resolution No.15452/10 of November 26, $2010^{49}$ the Supreme Arbitration Court defined that the only reliable remedy to protect the rights of a minority shareholder is a lawsuit on compensation of damages caused by improper calculation of the price of shares, which may be filed within six months from the date when the said shareholder became aware of his shares being written off his personal securities account.

The constitutional validity of the squeeze-out procedure was also analysed by the constitutional courts of Croatia and Portugal. In Croatia squeeze-out is regulated by two different laws: Companies Act, and Act on the takeover of joint stock companies, which have certain differences. ${ }^{50}$ The Constitutional Court considered the constitutional validity of provisions of Companies Act. Decisions of the Constitutional Court of Croatia Nos. U-I4120/2003, U-I-4237/2003, U-I-3099/2004, U-I-29/2005, and U-I-4056/2006 of February 21, 2007 (case SIEMENS AG Osterreich) ${ }^{51}$ stated that:

1. a minority shareholder, in relation to their share value, has exclusive property rights in company but not the right to manage the company. The only exception being an action to demand declaring the decision of the general meeting null and void by the court. This way, the legal status of the majority shareholder differs from that of the minority shareholder;

2. the major shareholder should be given the right to acquire the remaining shares provided that the minority shareholders are not injured. The regulations of Companies Act 'enable the major shareholder to stimulate and enhance the company's inner structure, protecting the minority shareholders from potential exploitation. Legally binding conditions protect the major shareholder from the potential manipulation from the minority shareholders as well', 'guarantee greater legal certainty to minority shareholders and their protection in regards to potential actions of the major shareholder which might, although legitimate, harm and weaken or completely annul the property rights of the minority shareholders.'

Besides the suit filed to the Constitutional Court, the minority shareholders also filed a suit to the Commercial Court of Zagreb to annul the decision of general meeting of SIEMENS AG Osterreich on squeeze-out due to procedural deficiencies made during the convening of the general meeting. The High Commercial Court of the Republic of Croatia (No. Pž-6487/04-8) satisfied the appeal filed by minority shareholders and forwarded the case for a new consideration to the court of first instance which declared the decision of the general shareholders meeting on the squeeze-out procedure void. ${ }^{52}$

48 Resolution of the Presidium of the Supreme Arbitration Court of the Russian Federation No. 443/11 of September 13, 2011.

49 Resolution of the Supreme Arbitration Court of the Russian Federation of No. 15452/10 of November 26, 2010.

50 Čulinović-Herc and Zubović (2013).

51 Ustavni sud Republike Hrvatske U-I-4120/2003.

52 Čulinović-Herc and Zubović (2013). 
In another case, a minority shareholder appealed against the price determined within the squeeze-out procedure by the majority shareholder. The expert appointed by the court of first instance performed revaluated the price of shares from 712 to $1762 \mathrm{HRK}$. The majority shareholder filed an appeal which was rejected by the High Commercial Court of the Republic of Croatia, and later filed a complaint to the Constitutional Court against the respective provisions of the law. The Constitutional Court in its decision No. U-III-3693/2007 of May 6, 2010 ${ }^{53}$ did not find a violation of the right of ownership of the majority shareholder nor a violation of freedom of business.

In Portugal, when the price of shares cannot be determined upon the criteria defined by the Securities Code, it shall be calculated by an independent auditor appointed by the regulatory authority. The Constitutional Tribunal of Portugal in its decision No. 491/2002 of January 22, $2003^{54}$ acknowledged the constitutional validity of the squeeze-out on the grounds of the prevailing right of majority over the minority of shareholders for the purpose of more efficient company management. It also pointed out that the lawmaker established procedural guarantees for minority shareholders, in particular, the right to fair calculation of compensation for the shares by an independent auditor and the right to sell-out.

The only constitutional court to render the squeeze-out procedure non-constitutional was the Constitutional Court of Georgia (decision of May 18, 2007). ${ }^{55}$ In its decision, the Constitutional Court of Georgia stated the following:

1. Article $53^{3}$ of Law of Georgia on Entrepreneurs does not conform to Article 21 (1), (2) of the Constitution of Georgia which provide that the property and right of to inherit shall be acknowledged and guaranteed; the abrogation of the universal right to property, or of the right to acquire, alienate and inherit property shall be impermissible, while any restrictions of those rights shall be permissible for the purpose of the pressing social need in the cases determined by law and in accordance with a procedure established by law. Any given norm, which appeared successful in one state, will not be necessarily successful in another legal, economic, social and political realm (para. 2).

2. the compulsory sale of the shares of minority stockholder to the majority shareholder cannot be considered as social need and legitimate aim, as it presents a 'restriction.' Such a construction would be incompatible with article 21.2 of the Constitution, which considers a restriction to be means for achieving an aim, not an aim itself (para. 17).

3. squeeze out of minority shareholders may not be justified by the statement that they exercise their legal rights, including right to apply to court. The legislator can also reasonably optimize the relevant norms of the Law on Entrepreneurs, which would be much easier means for pursuing the aim, than squeezing out the minority shareholders from a society (para. 22).

4. the will of majority shareholder to own all the shares of a company is clear and natural, though it cannot serve as justification for restriction of right to property. Concentration of more than $95 \%$ of voting shares in ownership of one stockholder do not automatically evidence creation of social necessity for compulsory sale of shares. Compulsory sale of shares shall only be carried out if it constitutes the necessary means for normal functioning and development of the relevant company (para. 26).

53 Ustavni sud Republike Hrvatske U-III-3693/2007.

54 Tribunal Constitucional; Acórdão N. ${ }^{\circ}$ 491/02.

55 Second Chamber Case 2/1-370, 382, 390, 402, 405 (2007). 
5. the evaluation of proportionality of compulsory sale of shares requires the assessment of two aspects:

a) whether the procedure of decision-making and enforcement of compulsory sale of shares is compatible with the abovementioned requirements;

b) whether the procedure for determination of price of shares guarantees a fair compensation for a minority shareholder.

If these two important aspects are not duly considered, even if the legitimate aim is present, the means employed will be inadequate and disproportional (para. 27).

6. Article $53^{3}$ of Law on Entrepreneurs manifestly violates the fair balance in favour of majority shareholder. It provides a majority shareholder with opportunity to acquire shares of minority stockholder even in cases, when it is not necessary for an enterprise. The minority shareholder is informed on decision of compulsory sale of shares via publication of the decision in the press and via insured mail. In these conditions, a minority shareholder is not merely deprived of any remedy to protect himself against abuse of economic power by the majority shareholder, but also, they are not granted a possibility to gain information on reasons for compulsory sale of shares and to express their position in this respect (para. 28).

7. Article $53^{3}$, section 3 provides for right to access to court for a minority shareholder merely in case, when an expert or broker company determined the price, though the law does not provide for a situation when the price, determined pursuant to the charter of a joint stock company is not acceptable for a minority shareholder (para. 32).

Thus, constitutional courts, except the one in Georgia, acknowledged the legislation on squeeze-out, adopted by their own countries, as constitutionally valid. The courts share a common position that the availability of guarantees of minority shareholders' rights is the necessary precondition for squeeze-out to be constitutional. Such guarantees, in the opinion of the courts, are:

- Compliance with the norms of the law that regulates squeeze-out.

- Presence of public interest and the proportionality of interference.

- Payment of fair compensation for the shares being purchased.

- Availability of judicial control over the squeeze-out procedure.

In July 2019, 47 Ukrainian parliament members plead to the Constitutional Court of Ukraine to review the Law implementing the squeeze out as being contradictory to a number of articles of the Constitution of Ukraine. The Constitutional Court rejected the plea in a resolution dated 10 October 2019 on the grounds of insufficient substantiation ${ }^{56}$ which effectively means that the Constitutional Court avoided dealing with the issue.

\section{SQUEEZE-OUT PROCEDURE IN THE ECTHR PRACTICE}

In accordance with Article 4 (3) of the Code of Commercial Proceedings of Ukraine and Article 17 of Law of Ukraine on enforcement of judgments and application of practice of the European Court of Human Rights, the judgments of the ECtHR and the European Convention on Human Rights are the prevailing sources of law for a national court.

${ }^{56}$ Resolution of the Great Chamber of the Constitutional Court of Ukraine No 45-y/2019 of 10 October 2019. 
The first and most famous the ECtHR case directly dealing with squeeze-out was Bramelid and Malmström v. Sweden. ${ }^{57}$ This case concerned the application of the squeezeout mechanism in accordance with the Swedish Law on Companies of 1977 effective at that time, which stipulated that any person holding over $90 \%$ of shares and voting rights in a company was entitled to force a minority shareholder to sell their shares at the price applied for the sale through a takeover bid, or at the price determined by arbitral award. The plaintiffs were minority shareholders in a famous Swedish shopping mall and their shares were purchased by the majority shareholder in the end of 1977 at the price determined by the arbitration committee consisting of three independent arbitrators, where one of such arbitrators had to be appointed by minority shareholders (p.77).

The application was not admitted to consideration by the ECtHR due to poor substantiation of violation of Article 1 of Protocol No.1 of the Convention (p.83, 86). The European Commission on Human Rights expressed an opinion that Swedish law, which in certain circumstances obliges minority shareholders to sell their shareholdings for a price determined by arbitrators, while allowing them the right to have shares purchased on the same terms, cannot be said to create inequality in their disfavour such as to constitute a violation out of the right to enjoyment or possessions.

In our opinion, squeeze-out is an outstanding case of depriving a person of their possessions and thus the reason why the ECtHR practices on compulsory deprivation of property can be addressed. For instance, in Sporrong and Lönnroth v. Sweden ${ }^{58}$ the Court stated that in cases regarding violation of Article 1 of Protocol 1 of the Convention, it 'must determine whether a fair balance was struck between the demands of the general interest of the community and the requirements of the protection of the individual's fundamental rights.' The search for this balance is inherent in the whole of the Convention and is also reflected in the structure of Article 1 (para.69).

In James and others $v$. the United Kingdom, ${ }^{59}$ the Court stated that compulsory transfer of the right of ownership in property from one person to another may in principle be viewed as a measure taken in the 'public interest' if it is done with the purpose of implementing legal social policy (para.39); transfer of ownership from one person to another without payment of the amount which more or less corresponds with the value of property naturally stands for a disproportionate interference which cannot be deemed justified in the context of Article 1 of Protocol 1.

In Offerhaus and Offerhaus v. Netherlands (Application No. 35730/97), ${ }^{60}$ the ECtHR stated that an interference with the peaceful enjoyment of possessions must strike a fair balance between the demands of the general interest of the community and the requirements of the protection of the individual's fundamental rights. Compensation terms under the relevant legislation are material to the assessment whether the contested measure respects the requisite fair balance and, notably, whether it imposes a disproportionate burden on the applicants. In this connection, the taking of property without payment of an amount reasonably related to its value will normally constitute a disproportionate interference (para.2)

Thus, deprivation of shareholders of their ownership in shares by squeeze-out rule is permissible only in the public interests and subject to the conditions provided for by law

57 Bramelid and Malmström v. Sweden (1982).

58 Sporrong and Lönnroth v. Sweden (1982).

59 James and others v. The United Kingdom (1986).

60 Offerhaus and Offerhaus v. Netherlands (2001). 
and the general principles of international law. The conflict of interests of the majority and minority shareholders determines the need to strike a balance between them. That said, a minority shareholder is an economically weak party in corporate relations and the squeeze-out leads to termination of rights of minority shareholders regardless of the will of the latter. ${ }^{61}$ The shareholder deprived of corporate control due to transfer of their shares in favour of the offeror shall, in any case, receive a fair compensation for forcibly written-off securities, otherwise it means a violation of one of the fundamental principles of protection of the ownership right and a deprivation of the right of ownership without fair compensation (Article 1 of Protocol 1 to the Convention on Human Rights).

This means that the ECtHR in these decisions:

1. did not a priori discard the possibility of considering the violation of the right of ownership at the compulsory deprivation of property owned by private persons only on the basis of the fact that the parties to the case did not include the State, thus admitting the application of Article 1 of Protocol 1 of the Convention to relations between private persons.

2. stated its position that the compulsory deprivation of property owned by private persons is only possible to achieve a legitimate public purpose, to maintain the principle of fairness and balance of interests, without placing an excessive burden upon the party deprived of their property.

3. decided that the compulsory deprivation of property owned by private persons should be compensated by the amount that approximates its real value.

\section{CONCLUSIONS}

The European approach shows that compulsory deprivation of minority shareholders of their ownership rights to shares is possible only in case it is prescribed by national law, subject to the conditions that a fair balance of interests has been maintained and full prior compensation of the market value of the shares has been paid. The current Ukrainian legislation on the squeeze-out does not meet these requirements and is the reason why the Ukrainian legal framework for the squeeze-out procedure on the basis of a takeover bid of the dominating interest holder needs further fine-tuning to safeguard minority shareholders' rights.

In this connection, it is necessary to develop an effective stock market in Ukraine as a general prerequisite for fair squeeze-outs. The national lawmaker should regulate the procedure of determining the market value of shares, implement the provisions of Directive 2004/25/EC as regards lapsing of the offer, revision of the offer, competing bids. In our view, the ways to improve the Ukrainian regulations in this area are as follows:

1. ensuring formation of fair price by means of counter offer from minority shareholders and investors at the take-over bid value.

2. opening a possibility of holding an open auction for the minority package sell-out.

3. setting special requirements on evaluators and special procedure of fair value estimation.

This corrective action would also solve the problem of a fair price for the shares which is acute for Ukrainian minority shareholders.

61 Posikalyuk (2015) 94-102. 


\section{LITERATURE}

A guide on public takeovers in Germany (2019) <http://www.allenovery.com/SiteCollectionDocuments/ Guide\%20to\%20public\%20takeovers\%20in\%20Germany\%20(email).pdf $>$.

Armour, J., Jacobs, J. B., Milhaupt C. J., 'The Evolution of Hostile Takeover Regimes in Developed and Emerging Markets: An Analytical Framework' (2011) 52 Harvard International Law Journal 221-84.

Belgium Squeeze-out Guide (IBA Corporate and M\&A Law Committee 2014) <www.ibanet.org/ Document/Default.aspx?DocumentUid=4D78956F-81ED-4FD7-A205-4B12897959D3> accessed 15 May 2020.

Cooke, S., 'Buying out minority shareholders' (2008) <http://www.practicallaw.com/2-254-3971> accessed 15 September 2019.

Čulinović-Herc, E., Zubović, A., 'Open issues of the squeeze out right in Croatian and EU court practices' $<$ https://bib.irb.hr/datoteka/652045.OPEN_ISSUES_OF_THE_SQUEEZE_OUT_RIGHT. doc $>$ accessed 15 September 2019.

Dignam, A. J., Allen, D., Company Law and the Human Rights Act 1998 (London/Edinburgh/Dublin, Butterworths 2000).

Franks, J. R., Mayer, C., Rossi, S., 'Spending Less Time with the Family: The Decline of Family Ownership in the United Kingdom' (2005) in A History of Corporate Governance around the World: Family Business Groups to Professional Managers: National Bureau of Economic Research Conference Report 581-612.

Gregoriou, G.N., Renneboog L., Corporate Governance and Regulatory Impact on Mergers and Acquisitions: Research and Analysis on Activity Worldwide since 1990 (Elsevier 2007).

Johnston, A., 'Takeover Regulation: Historical and Theoretical Perspectives on the City Code' (2007) 66 Cambridge Law Journal 423-32.

Johnston, A., The City Take-over Code (Oxford University Press 1980).

Kenyon-Slade, S., Mergers and Takeovers in the US and UK: Law and Practice (Oxford University Press 2004).

Kibenko, O., Suchasnyi stan ta perspektyvy pravovoho rehuliuvannia korporatyvnykh vidnosyn: porivnialno-pravovyi analiz prava YeEs, Velykobrytanii ta Ukrainy: Thesis (Current State and Prospects of the Legal Framework for Corporate Relations: Comparative Legal Analysis of the EU, UK and Ukrainian Law) (Yaroslav Mudriy National Law Academy of Ukraine 2006).

Pepin, M. M., 'Exclusivity of Appraisal - the Possibility of Extinguishing Shareholder Claims, 42 Case' (1992) 3 W. Res. L. Rev. 955-91 <https://scholarlycommons.law.case.edu/caselrev/vol42/ iss3/5> accessed 15 September 2019.

Popov, A., Obyazatelnoe predlozhenie: zaschita prav $i$ interesov aktsionerov pri pogloschenii (Mandatory Offer: Protecting the Rights and Interests of Shareholders During a Takeover) (Infotropic Media 2012).

Posykaliuk, O., 'Squeeze-out: dosvid YeEs ta perspektyvy vprovadzhennia v zakonodavstvo Ukrainy' (Squeeze-out: EU Experience and Prospects for Implementation in Ukrainian Legislation) in Yu. V. Belousov (ed), Problemy modernizatsii pryvatnoho prava $v$ umovakh yevrointehratsii [Problems of Modernization of Private Law in European Integration]: A Collection of Scientific Papers (Acad. F. G. Burchak Scientific-Research Institute of Private Law and Entrepreneurship 2015) 94-102.

Report of the High Level Group Company Law Experts on Issues Related to Takeover Bids (Brussels 2002) <http://europa.eu/rapid/press-release_IP-02-24_en.htm> accessed 15 September 2019.

Report of the High Level Group of Company Law Experts on Issues Related to Takeover Bids 27-8 (2002) < http://europa.eu/rapid/press-release_IP-02-24_en.htm> accessed 15 September 2019.

Shytkina, I., Korporativnoye pravo: Uchebnyi kurs [Corporate Law: A Training Course] (KNORUS 2011).

Skog, R., Does Sweden Need a Mandatory Bid Rule? A Critical Analysis (SUERF Amsterdam 1997).

Stepanov, D., 'Pogloschenie, osuschestvlyaemoe putyom priobreteniya krupnogo paketa aktsiy, i vyitesnenie minoritarnyih aktsionerov' (Takeover by the acquisition of a significant interest and crowding out minority shareholders) (2006) 3 Hozyaystvo i pravo [Economy and Law] 4-7. 
Switzerland Squeeze-out Guide IBA Corporate and M\&A Law Committee (2010) < https://www. vischer.com/fileadmin/uploads/vischer/Documents/Activities/Publikation_CMI_RMM_TGU_. pdf $>$.

Vos, T., Freeze-outs of minority shareholders: a comparative law and economics approach: Master thesis (KU Leuven Faculty of Law Academic Year 2015-2016).

Yoran (Jurkevitz), A., ‘Advanced Defensive Tactics Against Takeover Bids', (1973) 21 Am. J. Comp. L. 531-56.

\section{LEGAL MATERIAL}

Bramelid and Malmström v. Sweden App no 8588/79; 8589/79 (ECtHR, 12 October 1982).

Bundesverfassungsgericht; Beschluss der 1. Kammer des Ersten Senats vom 23. August $2000-1$ BvR 68/95 - Rn. (1-31).

Bundesverfassungsgericht; Beschluss der 3. Kammer des Ersten Senats vom 30. Mai 2007 - 1 BvR 390/04 - Rn. (1-39).

Bundesverfassungsgericht; Beschluss des Ersten Senats vom 27. April 1999 - 1 BvR 1613/94 - Rn. (1-80).

Commercial code (Obchodni zakonik) <https://www.wipo.int/edocs/lexdocs/laws/en/cz/cz053en.pdf $>$ accessed 15 September 2019.

Companies Act 2006. <http://www.legislation.gov.uk/ukpga/2006/46/pdfs/ukpga_20060046_en.pdf> accessed 15 September 2019.

Czech Constitutional Court; 2008/03/27 - Pl.ÚS 56/05: Squeeze-out <https://www.usoud.cz/en/ decisions/20080327-plus-5605-squeeze-out-1/> accessed 15 September 2019.

Decision of the Constitutional Court of the Russian Federation of July 3, 2007 No. 681-O-П on the complaints of citizens Y. Yu. Kolodkin and Yu.N. Shadeev <https://rg.ru/2007/11/10/syd-dok. html> accessed 15 September 2019.

Decision of the Constitutional Court of the Russian Federation of July 3, 2007 No. 713-O-P on the complaint of a citizen M. Y. Tsurkin <http://legalacts.ru/doc/opredelenie-konstitutsionnogo-sudarf-ot-03072007-n-713-o-p-po/> accessed 15 September 2019.

Decision of the Constitutional Court of the Russian Federation of March 7, 2007 No. 714-OP on the complaint of a citizen A.F. Petrov <http://legalacts.ru/doc/opredelenie-konstitutsionnogo-suda-rfot-03072007-n-714-o-p-po/> accessed 15 September 2019.

Decision of the Constitutional Court of the Russian Federation of May 29, 2012 No. 949-O on refusal to accept complaints of citizen S.A. Denisov <http://www.garant.ru/products/ipo/prime/ doc/70094942/> accessed 15 September 2019.

Decision of the Constitutional Court of the Russian Federation of February 24, 2004 No. 3-P on the case on verifying the constitutionality of certain provisions of Articles 74 and 77 of the Federal Law on Joint-Stock Companies <https://rg.ru/2004/03/02/ks-dok.html> accessed 15 September 2019.

Directive 2004/25/EC of the European Parliament and of the Council of 21 April 2004 on takeovers bids [2004] OJ L142/12.

Draft law on joint-stock companies of 25 November $2019<$ http://w1.c1.rada.gov.ua/pls/zweb2/ webproc4 1?pf3511=67468> accessed 15 May 2020.

Draft resolution of the National Securities and Stock Market Commission of Ukraine of 12 October $2018<\mathrm{https}: / /$ www.nssmc.gov.ua/en/proects_of_regular/pro-zatverdzhennya-polozhennya-prorestr-otsnyuvatchv/> accessed 15 May 2020.

Feldmühle Fall (BVerfG, 1BvL 16/60) (1962) 37 NJW, 1667 ff. <https://opinioiuris.de/ entscheidung/1294> accessed 15 September 2019.

Hanson Trust PLC v. SCM Corp. (1985) 774 F. 2d 47 <https://www.courtlistener.com/ opinion/2246601/hanson-trust-plc-v-scm-corp/> accessed 15 September 2019.

James and others $v$. The United Kingdom App no. 8793/79 (ECtHR, 21 February 1986).

Kodeks spółek handlowych z dnia 15 września $2000 \mathrm{r}<$ http://prawo.sejm.gov.pl/isap.nsf/download. xsp/WDU20000941037/U/D20001037Lj.pdf $>$ accessed 15 September 2019.

Offerhaus and Offerhaus v. Netherlands App no. 35730/97 (ECtHR 16 January 2001). 
On Amendments to Certain Legislative Acts of Ukraine on Increasing the Level of Corporate Governance in Joint-Stock Companies: Law of Ukraine of March 23, 2017.

On joint-stock companies: Law of Ukraine of 17 September, 2008.

Resolution of the Great Chamber of the Constitutional Court of Ukraine No 45-y/2019 of 10 October $2019<\mathrm{http} / /$ www.ccu.gov.ua/sites/default/files/docs/45 y_2019.pdf $>$.

Resolution of the National Securities and Stock Market Commission of Ukraine 624-CX-1-E of 12 April $2018<$ https://www.nssmc.gov.ua/documents/pro-rozglyad-skargi-publtchnogo-aktsonernogotovaristva-dtek-dnproenergo-vd-30-01-2018-v-8201-18-na-postanovu-pro-nakladennya-sanktsza-2/> accessed 15 September 2019.

Resolution of the Presidium of the Supreme Arbitration Court of the Russian Federation No. 443/11 of September 13, $2011<\mathrm{http}$ ://arbitr.ru/bras.net/f.aspx?id_casedoc=1_1_53188749-28ba-4531a3a3-51cd21c8ae89> accessed 15 September 2019.

Resolution of the Supreme Arbitration Court of the Russian Federation of November 26, 2010 No. BAC-15452/10 in case No. A08-8226 / 2009-30 on the refusal to transfer the case to the Presidium of the Supreme Arbitration Court of the Russian Federation <http://www.resheniya-sudov. $\mathrm{ru} / 2010 / 158659 />$ accessed 15 September 2019.

Securities Exchange Act of 1934, 48 Stat. 881 (6 June 1934).

Smith v. Van Gorkom 488 A.2d 858 (Delaware Supreme Court, 1985).

Sporrong and Lönnrot v. Sweden App no 7151/75 (A/52) (ECtHR, 23 September 1982).

The City Code on Takeovers and Mergers <http://www.thetakeoverpanel.org.uk/wp-content/ uploads/2008/11/code.pdf $>$ accessed - 15 September 2019

The Constitutional Court of Georgia. Second Chamber Case 2/1-370, 382, 390, 402, 405 (2007) 18 May <http://www.constcourt.ge/en/legal-acts/judgments/citizens-of-georgia-zaur-elashvili-sulikomashia-rusudan-gogia-and-others-and-public-defender-of-georgia-v-the-parliament-ofgeorgia-514.page> accessed 15 September 2019.

Tribunal Constitucional; Acórdão N. ${ }^{0}$ 491/02 <http://www.tribunalconstitucional.pt/tc/acordaos/ 20020491.html $>$ accessed 15 September 2019.

Trybunał Konstytucyjny 65/6/A/2005; Wyrok z dnia 21 czerwca 2005 r. Sygn. akt P 25/02 <https:// static1.money.pl/d/akty_prawne/pdf/DU/2005/124/DU20051241043.pdf $>$ accessed 15 September 2019.

Ustavni sud Republike Hrvatske U-I-4120/2003 Rješenje o neprihvaćanju prijedloga za ocjenu akata zakonodavnog tijela - zakoni i akti - snage zakona 21 February $2007<$ https://narodne-novine. nn.hr/clanci/sluzbeni/2007_04_36_1219.html> accessed 15 September 2019.

Ustavni sud Republike Hrvatske; U-III-3693/2007 Odluka o odbijanju ustavne tužbe May 06, 2010. $<$ https://sljeme.usud.hr/usud/praksaw.nsf/0/C12570D30061CE53C125771B003D2EE8?OpenDoc ument> accessed 15 September 2019. 